\title{
The role of collaborative journalism in WestPapua A Jubi and Tirto case study
}

\begin{abstract}
In this article, the author explores the collaboration between Tirto and Jubi in reporting on the Wamena and Jayapura riots in September 2019 in what has been described as the Papuan Uprising. The collaboration was greatly influenced by the desire of both media to improve the quality of news on human rights violations in West Papua. Tirto is an Indonesian online media outlet. Its journalists often criticise various government policies and the Indonesian political world through headlines, news and special articles. Tirto won an award as the Most Innovative Cyber Media in the 2017 Adinegoro Journalism Awards organised by the Indonesian Journalists Association. In the following year, Tirto became the only media outlet in Indonesia to receive an award from the International Fact-Checking Network (IFCN). Jubi is a general news media service from West Papua which reports on the West Papuan conflict, especially human rights issues. At the conceptual level, one can expect an accurate and in-depth report resulting from the journalism collaboration between Tirto and Jubi. However, at the practical level, a question arises about what the collaboration means for the life of West Papuan journalists? Research results using qualitative content analysis and interviews suggest that the collaborative journalism they created was able to restore West Papuan journalists'self-esteem. These findings can contribute to the enhancement of the knowledge in the field of journalism and provide valuable information for West Papuan journalists.
\end{abstract}

Keywords: collaborative journalism, content analysis, human rights, Indonesia, Jubi, Tirto, West Papua, West Papuan journalism

\section{ANA NADHYA ABRAR \\ Universitas Gadjah Mada, Yogyakarta}

\section{Introduction}

N 23 September 2019 riots broke out in Wamena, Papua that left 32 civilians dead and 65 injured. Initial reports said the riot in the West Papuan highlands city was provoked when a migrant teacher allegedly called a Papuan high school student a 'monkey'. This was the same racist insult that sparked mass riots across Indonesia after a similar incident occurred in the eastern 
Javanese city of Surabaya the previous month (Lamb, Cordell, \& Doherty, 2020; Robie, 2020). However, the matter was not quite that straightforward.

During subsequent student solidarity action at the Cenderawasih University Campus complex in Jayapura, 318 students were arrested and four people were reported killed, including one member of the armed forces (Firdaus, 2019)

The highly regarded Institute for Policy Research and Advocacy (ELSAM), , a human rights organisation, based in Jakarta, issued a statement criticising the government's behaviour. The statement warned that the security forces government was still brutally suppressing protests in West Papua. The security forces only carried out the orders of their superiors. The ELSAM Papua press release was titled 'The Wamena and Jayapura tragedy on September 23, 2019. The Jokowi Government must end militarism in the Land of Papua'.

ELSAM Papua expressed sympathy for the Papuans, promoting the declaration that Papuan Lives Matter. The events of September 23 were closely related to the Papua students' dormitory riot in Surabaya. Security forces arrested 42 Papuan students after that event (Abdi, 2019).

The events of September 23 can be categorised as violations of human rights as defined by the Universal Declaration of Human Rights (1948), such as right to life, liberty, personal security (Article 3), freedom from arbitrary arrest and exile (Article 9), the right to be considered innocent until proven guilty (Article 11), freedom of opinion and information (Article 19), and the right of peaceful assembly and association (Article 20) (UN, 2020). It also violated a number of rights guaranteed by Indonesian Law No. 39/1999. The issue of human rights in West Papua goes hand in hand with a desire to rearrange the relationship between the state power holders and citizens. In discussing the problem, Wignjosoebroto (2005, p. xiii) said:

Debate arises as to how much power and authority of a regime may be tolerated, and how broad the freedom of citizens, on the other hand it must always be recognised and must never be seized or violated.

That debate was never finished. He went on to say:

It is the duty of democrats to ensure that autocrats do not deny the basic rights of the people. Their efforts to do that, not only through advocacy actions to defend those whose rights have been violated. They also need to use more educative ways to make citizens aware of their natural and human rights, which have been denied, and are even deprived of, those who are in power. $(2005, \mathrm{p} . \mathrm{xvi})$

In Wignjosoebroto's opinion, every journalist in West Papua must be as a 'democratic agent', standing up to arbitrary authorities and making people aware of their human rights. 
Jubi had been attacked by the Indonesian government, with its website blocked for reporting news about the human rights violations in West Papua (Nopjr, 2019). In this atmosphere, Tirto invited the Jubi journalists to join them at the beginning of the following month in reporting on the riots. Ultimately, two Jubi journalists and one Tirto journalist were involved. Tirto used this opportunity to raise the morale of Jubi journalists whose website had been hacked by the Indonesian government.

\section{Indonesian media cooperation}

The press in Indonesia usually works together. The prominent form of co-operation, according to Ana Nadhya Abrar (2011), is co-operation in management and personal editorial collaboration:

Management cooperation is the cooperation of two newspapers with different editorial politics, working together to produce and market the results of each publication. Personal editorial cooperation is publishing several newspapers and magazines. For example, a group of people who are experts in the field of press editorials publish newspapers and magazines in several places. (pp. 30-31).

From the two cooperation models mentioned above, we can assume, first, that there will be one press media company that has many publications with accumulated models at one parent company. This phenomenon is often called a press conglomerate. The Jawa Pos and Kompas groups are two examples.

Second, we can also assume the role of individuals in the editorial field of press media is not large. Individuals cannot determine the ups and downs of the press. This is collective work, which is usually strongly influenced by the owners of press media companies. This condition is a challenge for the press in Indonesia facing de-politicisation. In 1991, Dhakidae argued that the condition of the ethics of Indonesian media politics has shifted to business ethics:

Previously the press media had a political audience. They were very loyal to the newspaper or magazine and chose not to read other newspapers or magazines when the newspaper or magazine they loved was not published. Now, it's easy for readers of a newspaper or magazine to switch to another newspaper or magazine. (Dhakidae, 1991, p. 3)

Kompas's publisher, Jakob Oetama, told the Indonesian Communication Bachelor Association Seminar II in Surabaya:

Press media companies are no longer just tools of struggle and sources of information, because newspaper founders also take business interests into account. (Kedaulatan Rakyat, 1991) 
Nasir (2005, p. 66) argued that media freedom and capital were important during the change in the structure of the Indonesian mass media from the Suharto order to the reformation order in 2004. As a result, readers have entered into a trade relationship with the media and no longer have the right to obtain important and useful information.

According to Prasetyo (2016), some journalistic information in West Papua comes only from security forces and public officials. The practice of journalism consisted mostly of interviews with several people rather than field reporting:

The news seems to be a parade of opinions. When there is an incident, government or military officials say A, then activists say B, and so on.

In contrast to the legitimate journalism practised by West Papuan media, according to Mambor and Sarmento (2020), there were about 18 online media outlets publishing hoaxes and propaganda about West Papua. This undermined news about human rights violations reported by the West Papuan media.

West Papuan journalists face threats when covering news on human rights violations in West Papua. This is the same threat identified by Singh (2020) that occurs across Melanesia. This requires a comprehensive approach to West Papuan journalists, especially who reports the news on human rights violations in West Papua, to make them feel confident in carrying out their professional duties through the cooperation of management and editorial staff from the Indonesian and West Papuan press. Stonbely (2017, p. 14) defines collaborative journalism as a formal or informal arrangement between a number of news organisations to share resources to increase the impact of the stories produced.

She continued:

In decades past, when profits were large and journalism as a field enjoyed a higher level of prestige, it felt natural for fellow journalists and newsrooms to see each other as competitors. Now, when profits are lean or non-existent, and trust in journalism has eroded, journalists have, in many cases, banded together for the betterment of their organizations, their product, and their audiences. (Stonbely, 2017, p. 17)

Cooperation with Jubi journalists was not Tirto's first collaboration with other media. Before working with Jubi, Tirto worked with Vice Indonesia, BBC Indonesia and The Jakarta Post to report on sexual harassment at the Gadjah Mada University campus (Sarjoko, 2020, p. 5).

\section{Human rights}

During decades of Indonesian control, human rights violations in West Papua have not stopped. According to the late Father Neles Tebay, a peace advocate from West Papua, the people of West Papua have experienced human rights violations since 1963. However, the issue of human rights violations in West 
Papua had not become a major issue for the major media in Jakarta, although they were raised at the UNESCO World Press Freedom Day conference hosted by Indonesia in 2017 (Robie, 2017, 2020; Wardah, 2017).

Practically, collaborative journalism has proven to be highly effective in reporting secrets, such as the Panama Papers. Kayser-Bril considers a best practice of collaborative journalism as follows:

...observers were struck by the collaborative nature of the effort. Hundreds of journalists worked together for months to produce ground-breaking reporting on tax evasion. (2017, p. 59).

The question is what kind of collaborative journalism is appropriate in reporting on the events in Wamena and Jayapura? Is it collaborative in the field of news gathering or news reporting?

Given the volatility of the situation in West Papua, a reasonable approach is collaboration in news gathering. West Papuan journalists and Indonesian journalists gather facts while Indonesian journalists write news. West Papuan journalists understand the field situation they face. They obtain facts and present suitable interviewees for Indonesian journalists to write up.

This cooperation model, borrowing the concept of Sarah Stonbely (2017,

\section{Figure1: Collaboration journalism between Jubi, Tirto, 2019}

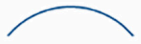

Collaborative Journalism

between Jubi and Tirto

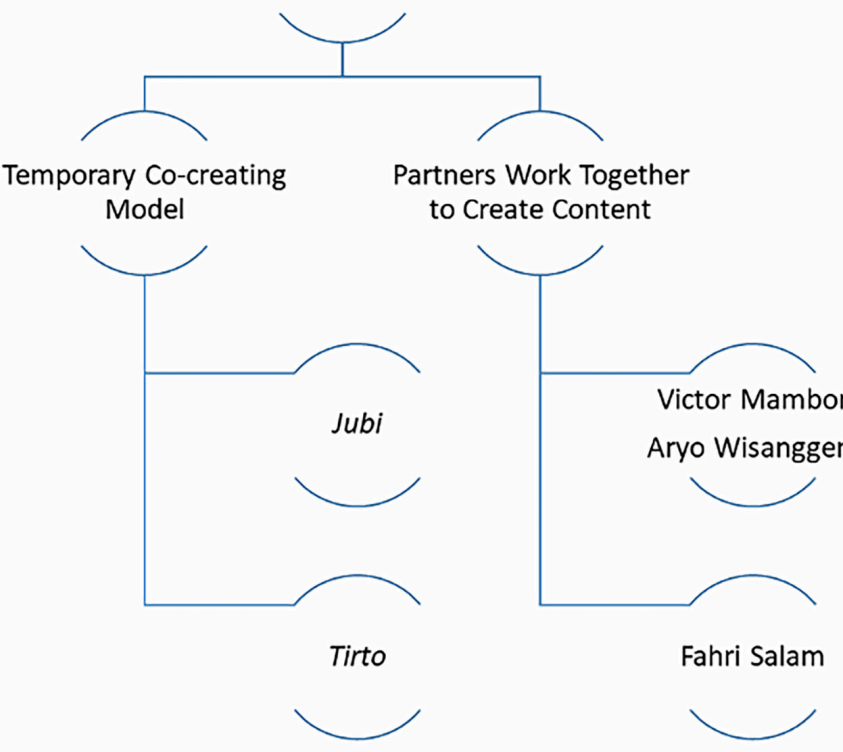

Note: Adapted from the collaboration model developed by Sarah Stonbely (2017, p. 21) 


\section{Table 1: Classification of news content by $5 \mathrm{~W}+1 \mathrm{H}$ approach}

News 1:Why did the Indonesian Government fail to prevent the incident in Wamena?

\begin{tabular}{|c|c|}
\hline What & $\begin{array}{l}\text { Fires broke out at several points, including Wouma Market, } \\
\text { Jayawijaya Regent's Office, Yapis University, building shops, } \\
\text { workshops and logistic shops on Hom-Hom Street, several } \\
\text { shops in Potikelek Market, Phike Street, as well as dozens of } \\
\text { houses, government offices and the power center of Wamena }\end{array}$ \\
\hline Who & $\begin{array}{l}\text { There is no information about who burned it. However, there } \\
\text { are data on who died: } 33 \text { people, } 25 \text { of whom were migrants }\end{array}$ \\
\hline Where & Wamena, the capital of Jayawijaya regency \\
\hline When & September 23, 2019 \\
\hline Why & $\begin{array}{l}\text { There is no information about why the buildings caught fire. } \\
\text { There was only information about Wamena PGRI high school } \\
\text { students protesting. They walked from their school to the Jay- } \\
\text { awijaya Regency Regent's Office. }\end{array}$ \\
\hline How & $\begin{array}{l}\text { All parts of the building burned down. Some of the residents } \\
\text { also burned }\end{array}$ \\
\hline News production & The report was made in collaboration with Tirto and Jubi. \\
\hline \multicolumn{2}{|c|}{ News 2: Wamena riot video: At least 11 West Papuans allegedly shot dead } \\
\hline What & 11 The West Papuans allegedly shot dead. \\
\hline Who & $\begin{array}{l}\text { It is not clear who the perpetrators of the shooting were. The } \\
\text { victims were: Eles Himan, } 25 \text { years-old, a university student; Elia- } \\
\text { kim Wetapo, } 25 \text { years old;) GestanusHisage, } 21 \text { years-old; Kelion } \\
\text { Tabuni, a university student; Ketron Kogoya, } 28 \text { years-old; Manu } \\
\text { Meage, (vii) Lawan Hesegem, } 28 \text { years-old; Marius Wenda, } 18 \\
\text { years-old; Naligi Wenda, security guard at Yudha Supermarket; } \\
\text { Nison Lokbere, } 19 \text { years-old and Yus Asso, } 25 \text {-years old }\end{array}$ \\
\hline Where & In various places in Wamena, the capital of Jayawijaya Regency \\
\hline When & September 23, 2019 \\
\hline Why & $\begin{array}{l}\text { Because they protested against the words of a PGRI Wamena } \\
\text { high school teacher who called Papuan monkeys. However, the } \\
\text { incident occurred on } 18 \text { September } 2019 . \text { Why did the riots take } \\
\text { place on } 23 \text { September } 2019 \text { ? }\end{array}$ \\
\hline How & $\begin{array}{l}\text { The protest raged violently. The army tried to break the crowd } \\
\text { with a warning shot. The police dispelled the crowd with tear } \\
\text { gas. However, } 42 \text { people were killed; } 17 \text { of whom were Papuans } \\
\text { and } 11 \text { of whom were confirmed as having died of gunshot } \\
\text { wounds. }\end{array}$ \\
\hline News production & The report was made in collaboration with Tirto and Jubi. \\
\hline
\end{tabular}

p. 21) is a 'temporary co-creating model, partners work together to create content'. Such cooperation is one-time cooperation and is limited to only one theme. The collaboration between the Jubi and the Tirto was deployed only once for reporting 


\begin{tabular}{|c|c|}
\hline What & $\begin{array}{l}\text { The mass demonstration by students in the regent's front } \\
\text { yard ended in chaos when the financial building behind the } \\
\text { office complex caught fire. A fire truck that tried to enter the } \\
\text { regent's office complex was prevented by the masses, pelted } \\
\text { with stones, so that efforts to extinguish the fire so that it would } \\
\text { not spread to other offices failed. }\end{array}$ \\
\hline Who & $\begin{array}{l}\text { At first the protestors were high school students at PGRI Wa- } \\
\text { mena. However, the numbers increased with the arrival of other } \\
\text { demonstrators. According to eyewitnesses, this other group } \\
\text { burned down the regent's office in Jayawijaya Regency }\end{array}$ \\
\hline Where & In various places in Wamena, the capital of Jayawijaya Regency \\
\hline When & September 23, 2019 \\
\hline Why & $\begin{array}{l}\text { Because it is considered rioters were protesting against racism. } \\
\text { According to the police, the allegation of racism was a hoax. }\end{array}$ \\
\hline How & $\begin{array}{l}\text { Victims were shot in different places. Some were shot in the } \\
\text { hips, waist, heart, back and buttocks.. }\end{array}$ \\
\hline News production & The report was made in collaboration with Tirto and Jubi. \\
\hline \multicolumn{2}{|c|}{ News 4: The church of West Papua save the non-West Papuans: 'Everyone is a nayak' } \\
\hline What & $\begin{array}{l}\text { Some churches in Wamena tried to save the non-West Pap- } \\
\text { uans, dismantled the doors of the houses where the people } \\
\text { were trapped, and brought them away from the centre of the } \\
\text { disturbance. }\end{array}$ \\
\hline Who & Rev. Simet Yikwa and Father Allo Dabi \\
\hline Where & $\begin{array}{l}\text { In the Wesaroma Pikhe Baptist Church and in the Office of the } \\
\text { Dean of the Central Mountains of Papua }\end{array}$ \\
\hline When & September 23, 2019 \\
\hline Why & $\begin{array}{l}\text { Because many people, both West Papuans, non-West Papuans } \\
\text { and people from outside the city of Wamena wanted to seek } \\
\text { safety. }\end{array}$ \\
\hline How & $\begin{array}{l}\text { They faced the attackers bravely. After that they accompanied } \\
\text { the safety seekers to the police station }\end{array}$ \\
\hline News production & The report was made in collaboration with Tirto and Jubi. \\
\hline
\end{tabular}

Note: Classification of the content of the four news stories produced by the collaborative team according to the $5 \mathrm{~W}+1 \mathrm{H}$ rule.

on the riot of September 23 five days after a PGRI (Persatuan Guru Republik Indonesia) teacher in Wamena called a student a 'monkey'. When described in a scheme, the collaboration can be seen in Figure 1.

\section{Methodology}

The author used four news stories produced as a result of the collaboration between Tirto and Jubi journalists. Qualitative content analysis was employed to gather data and assessed according to the principles of who/what/when/where/ 
why and how. Known as the Five Ws and One $\mathrm{H}$ model they are considered the basic six questions in factual information-gathering, and journalism (news writing style) research (Table 1). The key interrogation points are:

1. Who is it about?

2. What happened?

3. When did it happen?

4. Where did it happen?

Facts that matched the above model were used but the data was expanded through interviews with Victor Mambor and Aryo Wisanggeni from Jubi and Fahri Salam from Tirto, who had reported the articles.

\section{Results and discussion}

The collaboration produced four news stories. They were (1) Mengapa Pemerintah dan Keamanan Indonesia Gagal Cegah Rusuh Wamena? ('Why did the Indonesian Government fail to prevent the incident in Wamena?) written by Fahri Salam on 23 October 2019; (2) Video Rusuh Wamena: Sedikitnya 11 Orang Papua Diduga Tewas Ditembak ('Wamena parched video: At least 11 West Papuans allegedly shot dead', written by Fahri Salam on 24 October 2019, (3) Kematian Orang Papua dalam Peristiwa Wamena ('West Papuan deaths in the Wamena incident) written by Fahri Salam on 31 October 2019; and (4) (Gereja Papua Menyelamatkan Pendatang: 'Setiap Orang adalah Nayak' ('The church of West Papua saves the non-West Papuans: Everyone is a nayak', written by Fahri Salam on 1 November 2019. Reporter News 2 was successful in interviewing eyewitnesses from the non-West Papuans who had lived in Wamena for the past 40 years. Mambor considered that this tragedy was a mere power play. He said:

I had witnessed something like this in 1977, when Wamena was still in the forest, then, in 2000 and now with the same problem. The same item, after all. (Mambor, 2020) Whoever wants to cover the news in Wamena, he must have great guts because it is a conflict area. His physique must be strong, because the area in Wamena goes up and down the hill. His strength must be strong against the cold in a long journey. (Mambor, 2020)

\section{Discussion}

Are there basic rules about collaboration? According to Wissangeni (2020):

There are no basic rules. This is just a matter of networking, because basically every media wants to report good quality news. When there is the same network and interests, then the collaboration happens. (Wisanggeni, 2020)

Salam (2020) described the situation for the collaborating journalists in somewhat more nuanced terms: 
The reality at the scene did indeed require collaboration. The complexity of the issue of the Papuan news sources can only be solved by Jubi journalists. The security forces, government officials and people in charge of providing information said that most victims were the non-West Papuans. Public opinion was formed, the non-West Papuans became victims. Who is the perpetrator? Public opinion was formed: the perpetrators are the West Papuans. This makes the West Papuans hurt.

Wisanggeni (2020) said he had to explore the facts without causing 'new injuries.' This meant interviewing West Papuans:

However, it is difficult to find information from sources directly from the West Papuans. The situation there is not conducive and there is still tension. It is feared that there will be a clash again. There are journalists who have been evicted because the interviewees did not trust reporters. The resource person was very careful in giving information. Wisanggeni (2020) managed to interview the West Papuans successfully and seemed to open the way for other interviews:

It turns out that many West Papuans have become heroes, who have saved the non-West Papuans migrants in Wamena. Some were brought to church, honai, silimo, and mission houses. This fact has not been described by other media so far.

Collaborating with Tirto helped Wisanggeni regain his professional self-respect and overcome the pain caused by the Indonesian government-hacked the tabloidjubi.com website.

Through the four news stories, readers of Tirto discovered that the riots were triggered by hate speech delivered by a non-West Papuan teacher to the West Papuan students. Students in the class were offended. When their reporters pursued this angle they discovered this had happened long before the riots broke out and that it was difficult to pinpoint who actually caused the riot.

What is clear is that the Wamena riots stemmed from the handling of racism against West Papuans that occurred in Surabaya on August 19 that year. It can be said that the Indonesian police were dishonest in handling the racism case in Surabaya. The police were silent when members of a mass organisation surrounded a Papuan student dormitory in Surabaya, pelting Papuan students with stones, making racist expressions and firing tear gas.

This shows that the Indonesian government failed to resolve the racist issue against West Papuans in Surabaya. In this situation, a non-West Papua high school teacher delivered a hate speech to the West Papuan students. This exacerbated the West Papuans' sense of grievance. Presumably, this was used by a third party to create riots in Wamena.

Did Jubi reporters find out the facts about this third party? In searching for the information, they convinced themselves that they themselves were not being 
used as a tool of the Indonesian government:

We are not a government tool. Our task is to present the facts obtained in the scene. We found a lot of information about the perpetrators. However, we did not find the verified facts. Meanwhile we only write verified facts. So, the facts which are then presented are verified facts. (Wisanggeni, 2020)

The relationship between journalists and sources was like people protecting each other's existence. Such a relationship, according to Berkowitz (2009, p. 103), is a delicately negotiated relationship. Journalists stake their credibility and confidence in the stories they write. Meanwhile, sources risk their position on the information they convey. It is not surprising that journalists need to be careful in choosing the sources they interview with and sources not giving information to reporters carelessly.

\section{Writing}

Wisanggeni said Jubi and Tirto journalist shared the task of writing the stories:

Initially, we wrote individually. Then the news draft was shared with each other. Our draft was sent to Tirto, and the draft of Tirto was sent to us. We checked the accuracy. After that all drafts were sent to the Tirto. Tirto was the one [which] carried out the gatekeeping process and reported the news. (Wisanggeni, 2020)

This division of tasks caused the interpersonal relations between Jubi and Tirto journalists to run well. Nobody intervened in the duty of others. Borrowing the opinions of Kishimi and Koga, this is what must be done to maintain smooth interpersonal relations (2017, p. 53).

The relationship between Jubi and Tirto journalists was maintained because Jubi journalists acknowledge Tirto's seriousness as an online media outlet that had the integrity to report bad news about West Papua. Tirto's credibility was also proven. (Utama, 2020) commented:

In the midst of a crisis in public trust in online media, in 2016 Tirto emerged as a breath of fresh air in the world of online journalism. Tirto reports news not only as narrative and opinion-forming, but also brings in-depth data and analysis which is packaged into news texts, articles, infographics, and other journalistic products. The credibility of Tirto as an online media has begun to be recognised since it exposed the issue of rape of mining workers in West Papua (Utama, 2020, p. 4).

For Mambor (2020), the collaboration restored his damaged self-esteem because the news about the tragedy had not reached the readers.

What is important now is the sharpening of the themes of human rights violations that occurred in West Papua as objects of news coverage. 


\section{Conclusion}

The importance of the collaborative venture was in revealing a number of previously unknown facts about the Wamena riots. These were that the victims of human rights violations in Wamena were not only the non-West Papuans, but also the West Papuans; many West Papuans helped the non-West Papuans during the tragedy and the September 23 riots were a repeat of what had happened before in 1977 and 2000.

Jubi and Tirto journalists admit that there is still much that has not been revealed, but what has been uncovered may form a new opinion among the two news outlets' West Papuan and Indonesian readers. They may make Tirto readers more critical of the Indonesian government.

On a personal level the collaboration helped revive the sprits of the Jubi journalists following the government attack on their website. On both a professional and a personal level it reaffirmed the benefits of co-operation and collaboration between different news organisations, especially when they can benefit from the journalists' expertise in their own area.

\section{References}

Abdi, A.P. (2019, August 17). Kisah penangkapan 42 orang di asrama mahasiswa Papua Surabaya versi mahasiswa (The story of the arrest of 42 people in the student version of the Surabaya Papuan student dormitory). Tirto. Retrieved from https://tirto. id/kisah-penangkapan-42-orang-di-asrama-papua-surabaya-versi-mahasiswa-eguq

Abrar, A.N. (2011) Analisis pers: Teori dan praktik. (Press analysis: Theory and practice). Yogyakarta, Indonesia: Cahaya Atma Pustaka.

Abrar, A.N. (2020). 'Seolah-olah jurnalisme': Bagaimana represi kekuasaan memaksa pers Papua jadi corong negara ('It's as if journalism': How the repression of power forced the Papuan press to become the mouthpiece of the state). Retrieved September 7, 2021, from https://theconversation.com/seolah-olah-jurnalisme-bagaimana-represikekuasaan-memaksa-pers-papua-jadi-corong-negara-147935

Aditjondro, G.J. (2003). Kebohongan-kebohongan negara: Perihal kondisi objektif lingkungan hidup di nusantara (State lies: Regarding the objective environmental conditions in the archipelago). Yogyakarta, Indonesia: Pustaka Pelajar.

Berkowitz, D.A. (2009). Reporters and their sources. In Wahl-Jorgensen, K and Hanitzsch, T, The handbook of journalism studies (pp. 102-115). New York, NY, and London, UK: Routledge.

Bril-N.K. (2018) Collaboration - One tool among many. In Sambrook, R (Ed.), Global teamwork: The rise of collaboration in investigative journalism (pp. 59-63). Oxford, UK: Reuters Institute for the Study of Journalism.

Dhakidae, D. (1991). Pengantar diskusi (Introduction to discussion). Paper presented at desk editor training seminar. Yogyakarta, Indonesia, 27 February 1991.

ELSAM Papua. (2019, September 23). The Jokowi government must end militarism in the land of Papua). Retrieved from https://elsam.or.id/tragedi-wamena-dan-jayapura-pada23-september-2019-pemerintahan-jokowi-harus-akhiri-militerisme-di-tanah-papua/

ELSAM Papua. (2019, September 26). Tragedi Wamena dan Jayapura pada 23 September 2019, Pemerintahan Jokowi harus akhiri militerisme di Tanah Papua (The Wamena and Jayapura tragedy on September 23, 2019. 
Firdaus, F. (2019, September 23). At least 20 dead in protests in Indonesia's West Papua. Al Jazeera English. Retrieved from https:/www.aljazeera.com/news/2019/9/23/atleast-20-dead-in-protests-in-indonesias-west-papua

Gupta, A. (2017). Bringing collaborative journalism to the issue of international migration: An interview about the 19 million hackathon. Media Field Journals, 12, 1-19.

Kedaulatan Rakyat (1991, March 9). Implikasi pers industrial (Implications of the industrial press). Retrieved from https://repository.ugm.ac.id/136413/1/Analisis\%20 Pers.pdf

Kishimi, I. \& Koga, F. (2017). Berani tidak disukai (Dare not to be liked). Jakarta, Indonesia: Penerbit PT Gramedia Pustaka Utama.

Kleden, L. (1978). Manusia: Kerinduan yang tak selesai (Human: Unfinished desire). Horison, Majalah Sastra (Literary Magazine) 2(13), 39-42.

Kresna, M. (2019, August 22) Indonesia's stuttering to deal with racism against Papuans. Indepth Reporting, Retrieved from https://translate.google.com/translate?hl=en\&sl=id $\& \mathrm{tl}=\mathrm{en} \& \mathrm{u}=\mathrm{https} \% 3 \mathrm{~A} \% 2 \mathrm{~F} \% 2 \mathrm{Ftirto} . \mathrm{id} \% 2 \mathrm{Fkegagapan}-$ indonesia-menangani-rasismeterhadap-orang-papua-egK6\&prev $=$ search

Lamb, K., Cordell, M. \& Doherty, B. (2019, September 28). 'I feel like I'm dying': West Papua witnesses recount horror of police shootings. The Guardian. Retrieved from https:/www.theguardian.com/world/2019/sep/28/i-feel-like-im-dying-west-papuawitnesses-unrest-indonesia-police

Mambor, V. (2020, June 24). Interview with the author.

Mambor, V., \& da Costa Sarmento, P. (2020). West Papuan control: How red tape, disinformation and bogus online media disrupts legitimate news sources. Pacific Journalism Review : Te Koakoa, 26(1), 105-113. https://doi.org/10.24135/pjr.v26i1.1085

Nasir, Z. (2005). Perubahan struktur media massa Indonesia dari orde Soeharto ke orde reformasi (Changes in the structure of Indonesian mass media from the Soeharto order to the reform order). Jurnal Thesis, 4(2), 43-67.

Nopjr (2019, September 3). Suara Papua dan Jubi, oksigennya Papua dan Indonesia (The voice of Papua and Jubi, the oxygen of Papua and Indonesia). Qureta. Retrieved from https://www.qureta.com/post/suara-papua-dan-jubi-oksigennya-papua-dan-indonesia.

Prasetyo, S.A. (2016). Potret pers dan media di Papua: Belum hadir memenuhi hak atas informasi (Portrait of the press and media in West Papua: Not yet present fulfills the right to information). Retrieved from https://dewanpers.or.id/berita/detail/1026/ Potret-Pers-dan-Media-di-Papua:--Belum-Hadir-Memenuhi--Hak-Atas-InformasiOleh:-Stanley-Adi-Prasetyo

Robie, D. (2017). Indonesian double standards over press freedom endanger safety of Papuan journalists. Media Asia, 4(1), 40-47. https://doi.org/10.1080/01296612.201 7.1379812

Robie, D. (2020). Key Melanesian media freedom challenges: Climate crisis, internet freedoms, fake news and West Papua. Pacific Journalism Review : Te Koakoa, 26(1), 15-36. https://doi.org/10.24135/pjr.v26i1.1072

Salam, F. (2019a, October 23). Mengapa memerintah dan keamanan Indonesia gagal cegah rusuh Wamena? (Why did the Indonesian government fail to prevent restless Wamena?) Indepth Reporting. Retrieved from https://Tirto/mengapa-pemerintah-dankeamanan-indonesia-gagal-cegah-rusuh-wamena-eke3

Salam, F. (2019b, October 24). Video rusuh Wamena: Sedikitnya 11 orang Papua diduga tewas ditembak (Wamena parched video: At least 11 West Papuans allegedly shot dead). Indepth Reporting. Retrieved from https://Tirto/video-rusuh-wamenasedikitnya-11-orang-papua-diduga-tewas-ditembak-ekhb 
Salam, F. (2019c, October 31) Kematian orang Papua dalam peristiwa Wamena (Death of West Papuans in the Wamena incident). Indepth Reporting. Retrieved from https:// Tirto/kematian-orang-papua-dalam-peristiwa-wamena-ekR6

Salam, F. (2019d, November 1). Gereja Papua menyelamatkan pendatang: 'Setiap orang adalah nayak' (The church of West Papua saves the non-West Papuans: 'Everyone is nayak'). Indepth Reporting. Retrieved from https://Tirto/gereja-papua-menyelamatkan-pendatang-setiap-orang-adalah-nayak-ekVm

Salam, F. (2020, June 24). Interview with the author.

Sarjoko (2020). Praktik collaborative journalism di media online Indonesia (Studi kasus kolaborasi 'nama baik kampus' oleh jurnalis Tirto, BBC Indonesia. Vice Indonesia dan The Jakarta Post Tahun 2019) Collaborative journalism practices in Indonesian online media (Case study of collaboration 'Good name of campus' by journalists from Tirto, BBC Indonesia, Vice Indonesia, and The Jakarta Post in 2019). Unpublished master's thesis, Universitas Gadjah Mada, Indonesia.

Mambor, V., \& da Costa Sarmento, P. (2020). West Papuan control: How red tape, disinformation and bogus online media disrupts legitimate news sources. Pacific Journalism Review : Te Koakoa, 26(1), 105-113. https://doi.org/10.24135/pjr.v26i1.1085

Singh, S. (2020). The media and journalism challenges in Melanesia: Addressing the impacts of external and internal threats in Fiji, Papua New Guinea, Solomon Islands and Vanuatu . Pacific Journalism Review : Te Koakoa, 26(1), 48-62. https://doi. org/10.24135/pjr.v26i1.1095

Siregar, A. (2010). Bersemangat dalam kebebasan pers bersama Sjahrir (Passionate about freedom of the press with Sjahrir). In Badil, R., and Mangiang, M., Ciil. Jakarta, Indonesia: Kepustakaan Populer Gramedia.

Stonbely, S. (2017). Comparing models of collaborative journalism. Montclair, NJ: Center for Cooperative Media School of Communication and Media,

Undang-Undang Republik Indonesia No. 39/1999 Tentang hak asasi manusia. (Indonesian law No. 39/1999 Concerning human rights). Retrieved from https://komisiinformasi. go.id/?p=1795

United Nations. Universal Declaration of Human Rights. Retrieved from https://www. un.org/en/universal-declaration-human-rights/

Utama, N. (2020). Kritik Tirto terhadap presiden Jokowi. (Analisis wacana kritis artikel editorial Tirto periode September-Oktober 2019) (Tirto feedback to president Jokowi. (Critical discourse analysis of editorial article of Tirto for September-October 2019 period). Bachelor Thesis, Universitas Gadjah Mada, Indonesia.

Wardah, F. (2017). Survei LIPI: Pelanggaran HAM persoalan terbesar di Papua. (LIPI Survey. human rights violations are the biggest problem in West Papua). Retrieved from htps://www.voaindonesia.com/a/survei-lipi-pelanggaran-ham-persoalanterbesar-di-papua/4164959.html

Wignjosoebroto, S. (2005). Pengantar (Introduction). In Lubis, T.M., Jalan panjang hak asasi manusia (The long way to human rights) ((pp. xiii-xvii)). Jakarta, Indonesia: Penerbit PT Gramedia Pustaka Utama.

Wisanggeni, A. (2020, June 24). Interview with author.

Dr Ana Nadhya Abrar is a member of the Faculty of Social and Political Science at the Universitas Gadjah Mada, Yogyakarta.

ana.abrar@mail.ugm.ac.id 